\title{
Symptomatology of Citrus mosaic sadwavirus (CiMV) in Some Citrus Cultivars and Effect of CiMV Infection on Citrus Fruit Quality
}

\author{
Jae Wook Hyun (iD *, Rok Yeon Hwang, Cheol Woo Choi, Kyung Eun Jung, and Seung Gab Han \\ Citrus Research Institute, National Institute of Horticultural \& Herbal Science, RDA, Jeju 63607, Korea \\ (Received on July 15, 2019; Revised on January 3, 2020; Accepted on January 6, 2020)
}

Citrus mosaic sadwavirus (CiMV) is a closely related virus with the Satsuma dwarf virus (SDV) along with Navel orange infectious mottling virus (NIMV), Natsudaidai dwarf virus (NDV), and Hyugagatsu virus (HV). The present study found that the typical symptoms of CiMV-infected citrus fruits include the appearance of dark blue speckles or ringspots on fruit rinds and the browning of oil glands in the spots as rind coloring began. As rind coloring progressed, the spots gradually faded, whereas the browning of the oil glands worsened to the point that the tissues surrounding the oil glands became necrotic. In very early satsuma mandarins (Citrus unshiu 'Miyamoto Wase') and 'Setoka' cultivar ( $C$. hybrid 'Setoka') of late-maturity citrus, the symptomatic fruits were eventually dropped. And in early satsuma mandarin ( $C$. unshiu 'Miyakawa Wase'), the peel hardness of the virus-infected fruit $(1,618.3 \pm 305.5$, g-force $)$ was more than twice as hard as that of the healthy fruit $(636.5 \pm 39.1$, g-force). The ratio of flesh weight to total fruit weight was higher for the healthy fruit $(77.3 \pm$ $1.7 \%)$ than for the infected fruit $(70.7 \pm 0.6)$ and peel puffing was more severe in the infected fruit $(2.9 \pm 0.4$ $\mathrm{mm})$ than in the healthy fruit $(0.9 \pm 0.2 \mathrm{~mm})$. The soluble solids content in infected citrus fruits was less values than the healthy fruit by $0.5-1.5{ }^{\circ}$ Brix. These findings

\footnotetext{
*Corresponding author.

Phone) +82-64-730-4109, FAX) +82-64-733-9564

E-mail)hyunjaewook@korea.kr

ORCID

Jae Wook Hyun

https://orcid.org/0000-0002-4383-8554

(c) This is an Open Access article distributed under the terms of the Creative Commons Attribution Non-Commercial License (http:// creativecommons.org/licenses/by-nc/4.0) which permits unrestricted noncommercial use, distribution, and reproduction in any medium, provided the original work is properly cited.
}

Articles can be freely viewed online at www.ppjonline.org. reveal that CiMV infection on citrus trees reduces the fruit quality of citrus.

Keywords : Citrus mosaic sadwavirus, fruit quality, symptom

Handling Editor : Ju-Yeon Yoon

Citrus is one of the most important fruit crops worldwide, and the cultivation of late-maturity citrus cultivars including 'Setoka' (Citrus hybrid 'Setoka'), 'Kanpei' (C. hybrid 'Kanpei'), 'Ehime kashi No. 28' (C. hybrid 'Ehime kasha 28 gou'), and 'Shiranuhi' (C. hybrid 'Shiranuhi') is increasing, especially in Korea, where such cultivars are becoming economically important. However, because most citrus cultivars are propagated by grafting, viral pathogens that are transmitted by grafting can cause economic problems. In particular, late-maturity citrus cultivars are considered to be virus-sensitive. It has been reported that approximately 30 viruses or virus-like agents and 6 viroids were found in citrus trees worldwide (Ito et al., 2002; Korkmaz et al., 2000). Four viruses, namely Citrus tristeza virus (CTV), Citrus tatter leaf virus (CTLV), Citrus mosaic sadwavirus (CiMV), and Satsuma dwarf virus (SDV), and 5 viroids, Citrus bent leaf viroid (CBLVd), Hop stunt viroid (HSVd), Citrus viroid III (CVd-III), Citrus viroid IV (CVd-IV), and Citrus viroid OS (CVd-OS) have been reported to infect citrus trees in Korean (Hyun et al., 2009, 2017). The study screened 155 orchards for viral infection, using multiplex PCR, and detected either SDV or CiMV in $35.2 \%$ of the trees tested: $43.7 \%$ of 'Setoka' trees, $40.0 \%$ of 'Kanpei' trees, $32.6 \%$ of 'Ehimekashi No. 28' trees, and $26.8 \%$ of 'Shiranuhi' trees (Hyun et al., 2017). CiMV of them is known to directly damage fruits including spotting and blotching of the rinds (Ito et al., 2004; Iwanami and Koizumi, 2000). 
CiMV is a member of the genus Sadwavirus, closely related virus group with the SDV along with Navel orange infectious mottling virus (NIMV), Natsudaidai dwarf virus (NDV), and Hyugagatsu virus (HV) (Ito et al., 2004; Iwanami 2010). In previous study, SDV and CiMV isolates were distinctively divided into two groups based on phylogenetic analysis of PP2 gene cloned from 22 viral isolates from Korea, and it was found that CiMV and SDV isolates from Korea shared 95.5-96.2\% and 97.1-97.7\% sequence identity with isolates from Japan, respectively (Hyun et al., 2017). Importantly, it was reported that both the total fresh weight and fruit yield of very early satsuma mandarin $(C$. unshiu 'Miyamoto Wase') plants infected with SDV and CiMV were $\sim 60 \%$ and $25-45 \%$ lower, respectively, after four years of infection, when compared to healthy plants
(Imada et al., 1980). However, even though many studies have investigated detection methods and genes for citrus viruses, few have assessed the effect of the viruses, especially on fruit quality (Ito et al., 2002, 2004; Iwanami et al., 1999). Therefore, this study was carried out to investigate CiMV symptoms according to citrus cultivars and the effects of CiMV on quality of citrus fruit in Korea.

We observed CiMV typical symptoms on very early satsuma mandarin, early satsuma mandarin (C. unshiu 'Miyagawa Wase'), 'Setoka', and 'Kiyomi' (Fig. 1). CiMV was detected all trees showing typical symptoms by multiplex PCR assay (data not presented). The typical symptoms included the appearance of dark blue speckles or ringspots on fruit rinds and the browning of oil glands in the spots as rind coloring began. As the coloring

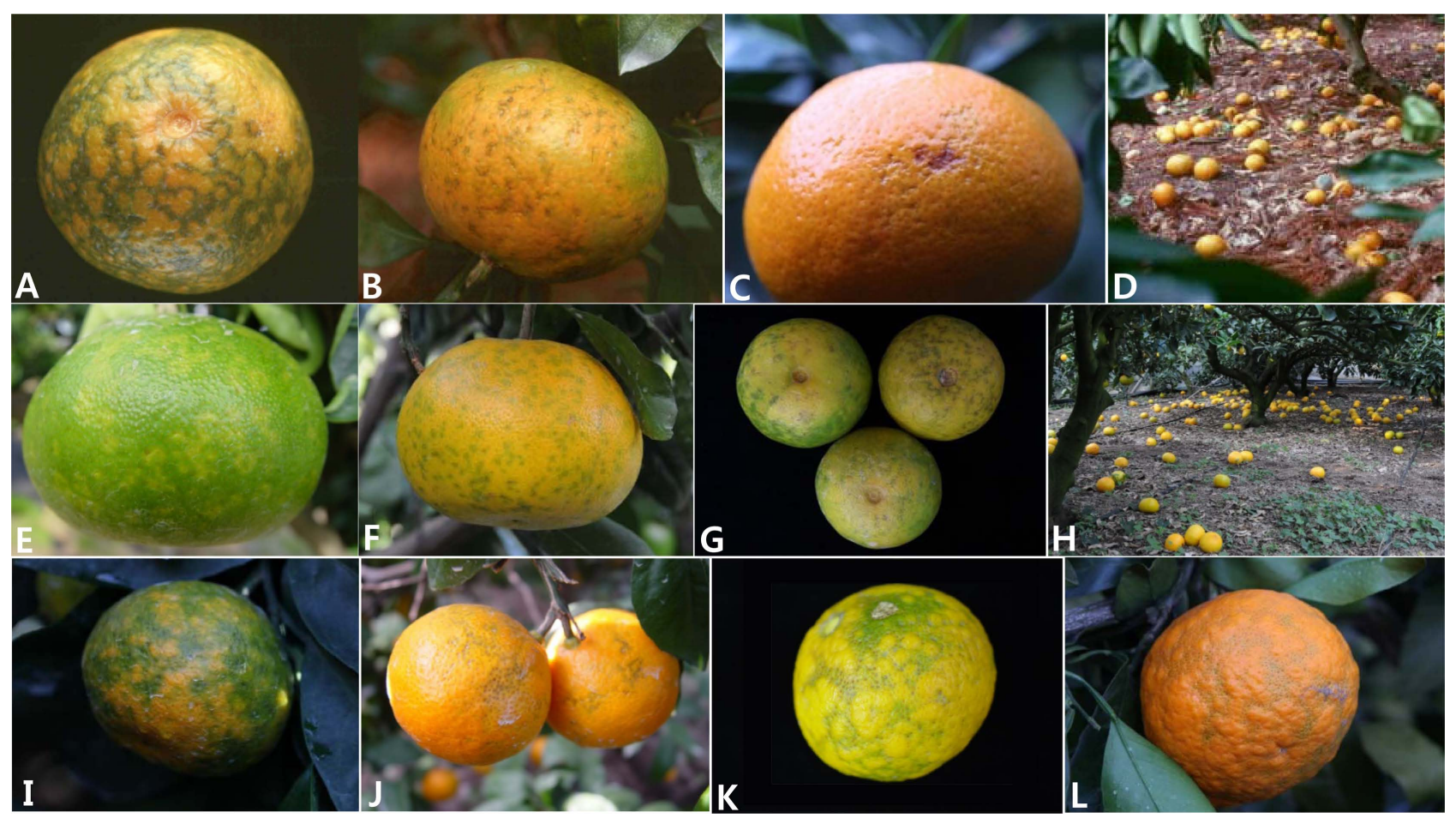

Fig. 1. Typical symptoms shown on citrus cultivars infected with Citrus mosaic sadwavirus (CiMV). (A-D) Very early satsuma mandarin. (E-H) ‘Setoka' citrus cultivar. (I, J) Early satsuma mandarin. (K, L) ‘Kiyomi’ citrus cultivar.

Table 1. Virus isolates and detection of citrus viruses

\begin{tabular}{llccccc}
\hline \multirow{2}{*}{ Virus isolate } & \multicolumn{4}{c}{ Origin } & \multicolumn{4}{c}{ Virus detection } & Reference \\
\cline { 3 - 6 } & & CTV & CTLV & SDV & CiMV & Hyun et al. (2017) \\
SM-1 & Early satsuma mandarin, Jeju & + & - & - & + & Hyun et al. (2017) \\
SM-26 & Early satsuma mandarin, Jeju & + & - & - & + & Hyun et al. (2017) \\
Jung-CiMV-3 & Early satsuma mandarin, Jeju & + & - & - & + & Hyun et al. (2017) \\
Nam-CiMV & Early satsuma mandarin, Jeju & + & - & - & + & In this study \\
Sehwa & Early satsuma mandarin, Jeju & + & - & - & + & \\
\hline
\end{tabular}

CTV, Citrus tristeza virus; CTLV, Citrus tatter leaf virus; SDV, Satsuma dwarf virus; CiMV, Citrus mosaic sadwavirus. 
Table 2. Primers used to detect the 4 citrus viruses in uniplex or multiplex PCR

\begin{tabular}{|c|c|c|c|c|c|}
\hline \multirow{2}{*}{ Target (virus) } & \multicolumn{2}{|r|}{ Primers } & \multirow{2}{*}{$\begin{array}{l}\text { Amplified } \\
\text { gene }\end{array}$} & \multirow{2}{*}{$\begin{array}{l}\text { Product size } \\
\text { (bp) }\end{array}$} & \multirow{2}{*}{ Reference } \\
\hline & Name & Sequence $\left(5^{\prime} \rightarrow 3^{\prime}\right)$ & & & \\
\hline \multirow[t]{2}{*}{ CTV } & CTV-Po-F & 5'-GTGGCCAATAGGTCCGTAGA-3' & \multirow[t]{2}{*}{$\mathrm{CP}$} & \multirow[t]{2}{*}{412} & \multirow{2}{*}{$\begin{array}{c}\text { Hyun et al. } \\
\text { (2017) }\end{array}$} \\
\hline & CTV-Po-R & 5'-CGGGTCTCAACCTAGCCATA-3' & & & \\
\hline \multirow[t]{2}{*}{ CiMV } & Sadwa(F) & 5'-ACGTTCTTTCCAAGGGGAGT-3' & \multirow[t]{2}{*}{ PP2 } & \multirow[t]{2}{*}{818} & \multirow{2}{*}{$\begin{array}{l}\text { Hyun et al. } \\
\text { (2017) }\end{array}$} \\
\hline & Sadwa(R) & 5'-CTCCATCAAGGGAGTTTGGA-3' & & & \\
\hline \multirow[t]{2}{*}{ SDV } & $\operatorname{SDV}(2014)-\mathrm{F}$ & 5'-CAACACATCGGGAGGAAACT-3' & \multirow[t]{2}{*}{ PP2 } & \multirow[t]{2}{*}{745} & \multirow{2}{*}{$\begin{array}{l}\text { Hyun et al. } \\
\text { (2017) }\end{array}$} \\
\hline & $\operatorname{SDV}(2014)-\mathrm{R}$ & 5'-AGCATGGAAGATGGACCTTG-3' & & & \\
\hline \multirow[t]{2}{*}{ SDV/CiMV } & PP2-3(F) & 5'-GCACGGTCTCTCACTCAGGGA-3' & \multirow[t]{2}{*}{ PP2 } & \multirow[t]{2}{*}{1,139} & \multirow[t]{2}{*}{ In this study } \\
\hline & PP2-4(R) & 5'-TACCTGCAAATATATCGCAGGTTG-3' & & & \\
\hline \multirow[t]{2}{*}{ CTLV } & CTLV(2013)-F & 5'-CGAAAACCCCTTTTTGTCCT-3' & \multirow[t]{2}{*}{$\mathrm{CP}$} & \multirow[t]{2}{*}{607} & \multirow{2}{*}{$\begin{array}{c}\text { Hyun et al. } \\
\text { (2017) }\end{array}$} \\
\hline & CTLV(2013)-R & 5'-ATAGACCCGGCAAAGGAACT-3' & & & \\
\hline \multirow[t]{2}{*}{ Actin } & Actin-F & 5'-TCCACCATGTTCCCAGGTAT-3' & \multirow[t]{2}{*}{ Actin } & \multirow[t]{2}{*}{210} & \multirow{2}{*}{$\begin{array}{c}\text { Hyun et al. } \\
\text { (2017) }\end{array}$} \\
\hline & Actin-R & 5'-CATCTCTGTCTGCCACCTGA-3' & & & \\
\hline
\end{tabular}

CTV, Citrus tristeza virus; CiMV, Citrus mosaic sadwavirus; SDV, Satsuma dwarf virus; CTLV, Citrus tatter leaf virus.

progressed, the spots gradually disappeared, but browning of the oil glands became worse and eventually the tissues surrounding the oil glands became necrotic (Fig. 1). The five isolates, SM-1, SM-26, Jung-CiMV-3, NamCiMV, and Sehwa, were collected from each of early satsuma mandarin trees showing CiMV typical symptoms in Namwon, Jeju to assay fruit quality (Table 1). The scions from each of the satsuma mandarin trees were grafted onto trifoliate orange rootstock, maintained in a greenhouse and used to detect viruses. For diagnosis of CTV, CTLV, and SDV/CiMV, multiplex PCR was performed using LiliF Citrus Virus Muliplex PCR Kit (catalog No. IP11075, iNtRON Biotechnology Inc., Seongnam, Korea) with CTVPo, PP2-3/4, CTLV-2013, and actin primer sets (Table 2, Fig. 2). And SDV and CiMV was specifically detected by

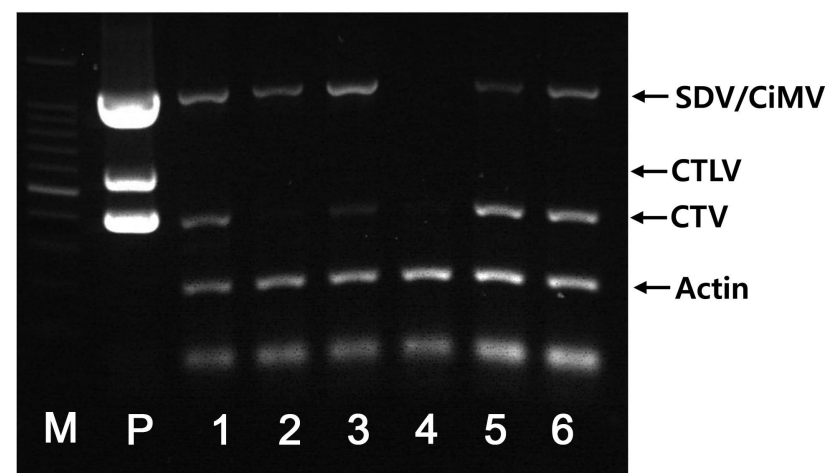

Fig. 2. Simultaneous detection of citrus viruses using multiplex PCR. Lane M: 100-bp DNA ladder; lanes 1-6: virus isolates from orchard. SDV, Satsuma dwarf virus; CiMV, Citrus mosaic sadwavirus; CTLV, Citrus tatter leaf virus; CTV, Citrus tristeza virus. uniplex PCR with SDV-2014 and Sadaw primer sets (Table 2), respectively, using Accupower Hotstart PCR pemimix (catalog No. K-5051, Bioneer, Daejeon, Korea). Total RNA for diagnosis was extracted from approximately 20 mg of young citrus leaves using TRIzol Reagent (catalog No. 15596-026, Invitrogen, Carlsbad, CA, USA) according to the manufacturer's protocol. The RNA was dissolved in $100 \mu \mathrm{l}$ FORMAzol solution (Molecular Research Center, Cincinnati, OH, USA) for stabilization of RNA solubilization and stored in $-20^{\circ} \mathrm{C}$ or $-70^{\circ} \mathrm{C}$. cDNA was prepared using a TOPscript cDNA synthesis kit (catalog No. EZ105S, Enzynomics, Daejeon, Korea) according to the manufacturer's protocol. The PCR amplifications were performed in a programmable thermocycler (model T-Gradient Thermoblock, Biometra, Göttigen, Germany), using an initial denaturation step of $95^{\circ} \mathrm{C}$ for 2 min followed by 35 amplification cycles of denaturation at $94^{\circ} \mathrm{C}$ for $30 \mathrm{~s}$, annealing at $60^{\circ} \mathrm{C}$ for $1 \mathrm{~min}$, and extension at $72^{\circ} \mathrm{C}$ for $2 \mathrm{~min}$,

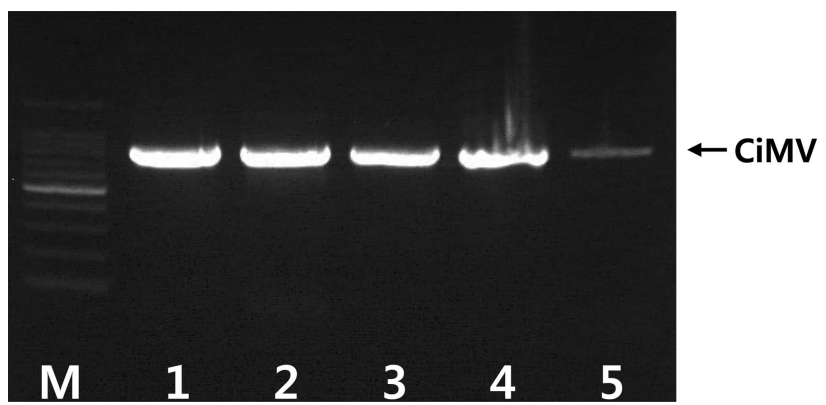

Fig. 3. Uniplex PCR for detection of of Citrus mosaic sadwavirus (CiMV) using Sadwa primer set. Lane M: 100-bp DNA ladder; lanes 1-5: Isolate SM-1, SM-26, Jung-CiMV-3, Nam-CiMV, and Sehwa, respectively. 
and a final extension at $72^{\circ} \mathrm{C}$ for $10 \mathrm{~min}$. After PCR, $12 \mu \mathrm{l}$ of the product was electrophoresed in a $1.0 \%$ agarose gel in $1 \times$ TAE buffer for $30 \mathrm{~min}$ at $3 \mathrm{~V} / \mathrm{cm}$ and visualized by ethidium bromide staining. A 100-bp DNA Ladder (catalog no. 3407A, Takara, Tokyo, Japan) was used as a molecular weight markers. As a result, the five trees were coinfected with CiMV and CTV (Table 1, Figs. 2 and 3). And, a total of 100 fruits exhibited typical symptoms were harvested from the four infected trees (isolate SM-1, SM-26, JungCiMV-3, and Nam-CiMV) of early satsuma mandarin in early December, and both peel hardness and degree of puffing were compared to those of symptomless fruits from healthy trees. Peel hardness was measured using a TA-XT2 texture analyzer (Stable Micro System, Godalming, UK) according to the manufacture's protocol. The peel hardness of the virus-infected fruit $(1,618.3 \pm 305.5$, $\mathrm{g}$-force) was more than twice as hard as that of the healthy fruit ( 636.5 \pm 39.1 , g-force) (Table 3). Furthermore, the ratio of flesh weight to total fruit weight was higher for the healthy fruit $(77.3 \pm 1.7 \%)$ than for the infected fruit $(70.7 \pm 0.6)$ (Table 3). Meanwhile, degree of peel puffing was measured as the interval between the pericarp and underlying segments. Peel puffing was more severe in the infected fruit $(2.9 \pm 0.4$ $\mathrm{mm})$ than in the healthy fruit $(0.9 \pm 0.2 \mathrm{~mm})$ (Table 3$)$.

One hundred fruits were harvested from each of three infected (Jung-CiMV-3, Nam-CiMV, and Sehwa) and three healthy trees both on October 27, during the early stage of coloring, and November 16, 2015, the late of coloring. And then both the titratable acidity (TA) and soluble solids content (SSC) of the fruits were analyzed. SSC was recorded using a refractometer (PR-101, Atago Co., Osaka, Japan). TA was also determined by adjusting the $\mathrm{pH}$ to 8.1 with $0.1 \mathrm{~N} \mathrm{NaOH}$ after adding $20 \mathrm{ml}$ distilled water in $5 \mathrm{ml}$ fruit juice. In fruits harvested in October 27, the SSC and TA of the healthy fruit was $9.1 \pm 0.2^{\circ}$ Brix and $1.20 \pm 0.11 \%$, respectively, whereas that of the infected fruit was 8.37 $\pm 0.31{ }^{\circ}$ Brix and $1.20 \pm 0.14 \%$, respectively (Table 4). In fruits harvested in November 16, the SSC and TA of the healthy fruit was $10.43 \pm 0.36^{\circ}$ Brix and $1.30 \pm 0.15 \%$, respectively, whereas that of the infected fruit was $8.87 \pm 0.44$ ${ }^{\circ}$ Brix and $1.17 \pm 0.26 \%$, respectively (Table 4 ). Thus, the results of the present study confirmed that CiMV reduces the commercial quality of citrus fruits and affects internal quality characteristics, such as SSC, even though the trees were coinfected with CiMV and CTV because these CTV isolates were mild strain by enzyme-linked immunosorbent assay using MCA-13 antibody (data not presented). Practically, though CTV was detected in $72.1 \%$ of 775 surveyed trees, there were no any CTV symptoms (Hyun et al., 2017). And it is not to be said that CTV did not affect the expression of CiMV at all because the most CTV were mild strains, but since the typical symptoms of CTV did not appear but only the typical symptoms of CiMV, the symptoms of trees investigated in this study might be mainly induced by CiMV infection. However, even if CTV is mild strain, the possibility of affecting the virus severity by coinfection with CiMV cannot be ruled out.

Previous studies have reported that the typical symptoms of CiMV infection, in certain cultivars, such as satsuma mandarin, include spotting and blotching of the fruit rind (Iwanami and Koizumi, 2000). Indeed, the present study, which surveyed citrus fruits in the Jeju area, found that the typical symptoms of CiMV-infected fruits included the appearance of dark blue speckles or ringspots on fruit rinds and the browning of oil glands in the spots as rind coloring began. As the coloring progressed, the spots gradually

Table 3. Effect of Citrus mosaic sadwavirus (CiMV) infection on the quality of citrus fruit

\begin{tabular}{cccc}
\hline & Peel hardness $(\text { g-force })^{\mathrm{a}}$ & ${\text { Flesh weight }(\%)^{\mathrm{b}}}$ & ${\text { Peel puffing }(\mathrm{mm})^{\mathrm{c}}}$ \\
\hline Healthy fruit & $636.5 \pm 39.1 \mathrm{a}$ & $77.3 \pm 1.7 \mathrm{a}$ & $0.9 \pm 0.2 \mathrm{a}$ \\
Infected fruit & $1,618.3 \pm 305.5 \mathrm{~b}$ & $70.7 \pm 0.6 \mathrm{~b}$ & $2.9 \pm 0.4 \mathrm{~b}$ \\
\hline
\end{tabular}

${ }^{a}$ Peel hardness was assayed using a TA-XT2 texture analyzer (Stable Micro System, Godalming, UK).

${ }^{\mathrm{b}}$ Flesh weight (\%) was calculated as (flesh weight/fruit weight) $\times 100 \%$.

${ }^{\mathrm{c}}$ Degree of peel puffing was measured as the spacing $(\mathrm{mm})$ between the peel and the underlying segments.

Table 4. Effect of Citrus mosaic sadwavirus (CiMV) on the sugar and acid contents of citrus fruit

\begin{tabular}{lcccc}
\hline \multirow{2}{*}{ Survey date } & \multicolumn{2}{c}{ Soluble solids content $\left({ }^{\circ}\right.$ Brix $)$} & \multicolumn{2}{c}{ Titratable acidity (\%) } \\
\cline { 2 - 5 } & Healthy fruit & Infected fruit & Healthy fruit & Infected fruit \\
\hline Oct 27 & $9.10 \pm 0.24 \mathrm{a}^{\mathrm{a}}$ & $8.37 \pm 0.31 \mathrm{~b}$ & $1.20 \pm 0.11 \mathrm{a}$ & $1.20 \pm 0.14 \mathrm{a}$ \\
Nov 16 & $10.43 \pm 0.36 \mathrm{a}$ & $8.87 \pm 0.44 \mathrm{~b}$ & $1.30 \pm 0.15 \mathrm{a}$ & $1.17 \pm 0.26 \mathrm{a}$ \\
\hline
\end{tabular}

${ }^{a}$ Numbers within a column followed by different letters are significantly different $(P=0.05)$ according to Duncan's multiple range test. 
disappeared, but browning of the oil glands became worse and eventually the tissues surrounding the oil glands became necrotic (Fig. 1). In very early satsuma mandarins and 'Setoka' cultivar of late-maturity citrus, many of the symptomatic fruits were eventually dropped (Fig. 1D and H). Even though many citrus trees are infected with CiMV, there were trees that showed no typical symptoms. In fact, during some years, some trees did not exhibit any typical symptoms, even though CiMV infection was known. Although unconfirmed, it is possible that the inconsistent display of symptoms is a result of virus density or environmental conditions. It has been reported CiMV isolate $\mathrm{Ci}$ 968 causes mosaic patterns on citrus fruit rinds, whereas infection by the other CiMV isolates (i.e., ND-1, LB-1, and Az-1) does not, and plural CiMV variants have been detected from a single citrus tree (Ito et al., 2007; Iwanami et al., 2001). Many trees were infected with CiMV, but typical symptoms were observed on only some trees. This is possible that non-pathogenic CiMV isolates are there.

The present study confirmed that CiMV infection on citrus cultivars reduce the quality of citrus fruits by reducing SSC, exacerbating peel puffing, and reducing flesh weight. Therefore, CiMV-infected trees should be removed from citrus orchards so that the infected fruits should not be distributed to the market for the competitiveness of the citrus industry.

\section{Acknowledgments}

This study was supported by a research program (Project No. PJ01255502) for horticultural science \& technology development, National Institute of Horticultural and Herbal Science, Rural Development Administration, Republic of Korea.

\section{References}

Hyun, J. W., Hwang, R. Y. and Jung, K. E. 2017. Development of multiplex PCR for simultaneous detection of citrus viruses and the incidence of citrus viral diseases in late-maturity citrus trees in Jeju Island. Plant Pathol. J. 33:307-317.

Hyun, J. W., Min, B. K., Kim, H. J., Lee, P. H. and Kim, K. S. 2009. Simultaneous detection of seven citrus viroids from citrus plants by multiplex real-time PCR. In: 2009 KSPP Annual Meeting and International Conference, p. 204. The Korean Society of Plant Pathology, Seoul, Korea.

Imada, J., Tanaka, H. and Narisawa, N. 1980. The effect of satsuma dwarf virus and citrus mosaic virus on the growth of citrus trees. Bull. Fruit Trees Res. Stn. E 3:75-82 (in Japanese).

Ito, T., Ieki, H. and Ozaki, K. 2002. Simultaneous detection of six citrus viroids and Apple stem grooving virus from citrus plants by multiplex reverse transcription polymerase chain reaction. J. Virol. Methods 106:235-239.

Ito, T., Shiotani, H., Iwanami, T., Ozaki, K. and Muramoto, K. 2007. Genetic diversity and a heterogeneous population of Citrus mosaic virus within a single citrus tree. J. Gen. Plant Pathol. 73:147-151.

Ito, T., Iwanami, T., Ieki, H., Shimomura, K., Shimizu, S. and Ito, T. 2004. A new virus related to Satsuma dwarf virus: the nucleotide sequence of the 3'-terminal regions of Hyuganatsu virus RNAs 1 and 2. Arch. Virol. 149:1459-1465.

Iwanami, T. 2010. Properties and control of Satsuma dwarf virus. JARQ 44:1-6.

Iwanami, T. and Koizumi, M. 2000. Satsuma dwarf virus group. In: Compendium of citrus diseases, eds. by L. W. Timmer, S. M. Garnsey and J. H. Graham, p. 59. American Phytopathological Society, St. Paul, MN, USA.

Iwanami, T., Kondo, Y. and Karasev, A. V. 1999. Nucleotide sequences and taxonomy of satsuma dwarf virus. J. Gen. Virol. 80:793-797.

Iwanami, T., Kondo, Y., Kobayashi, M., Han, S. S. and Karasev, A. V. 2001. Sequence diversity and interrelationships among isolates of satsuma dwarf-related viruses. Arch. Virol. 146:807813.

Korkmaz, S., Garnsey, S. M., Chagas, C. M., Derrick, K. S., Barthe, G. A., Iwanami, T., Koizumi, M., Miyakawa, T., Ito, T., Lee, R. F., Bar-Joseph, M., da Graca, J. V., Ahlawat, Y. S. and Moreno, P. 2000. Graft-transmissible, systemic diseases. In: Compendium of citrus diseases, eds. by L. W. Timmer, S. M. Garnsey and J. H. Graham, pp. 46-48. American Phytopathological Society, St. Paul, MN, USA. 